Vol. 1 No. 3 Desember 2021 e-ISSN : 2797-3344 P-ISSN : 2797-3336

\title{
UPAYA PENINGKATAN KEMAMPUAN GURU \\ DALAM MENGGUNAKAN MEDIA PEMBELAJARAN MELALUI SUPERVISI \\ AKADEMIK PADA MASA PANDEMI COPID-19 DI SDN 3 BERIRIJARAK \\ KECAMATAN WANASABA
}

\author{
KAHARUDDIN \\ SDN 3 Beririjarak Kecamatan Wanasaba Kabupaten Lombok Timur \\ kaharuddin@gmail.com
}

\begin{abstract}
ABSTRAK
Tujuan dari penelitian tindakan sekolah (PTS) ini adalah untuk mengetahui sejauh mana supervisi yang dilakukan oleh kepala sekolah yang diikuti dengan pemberian pembinaan/perlakuan terhadap guru-guru sasaran dapat meningkatkan kemampuan guru tersebut dalam menerapkan model-model pembelajaran di kelas. Dalam penelitian tindakan sekolah (PTS) ini dilakukan dalam 2 siklus, dari hasil tindakan yang dilakukan terbukti dapat meningkatkan kemampuan guru dengan mencapai standar ideal. Pada siklus I peningkatan kemampuan guru setelah dilakukan supervisi kelas setelah dilakukan pembinaan tentang pemanfaatan media pembelajaran baru mencapai sekitar 33,33\% pada siklus II dapat meningkat menjadi $100 \%$. Skor rata-rata yang diperoleh setelah dilakukan supervisi kelas pada siklus I sebesar 69,67 dan meningkat pada siklus II menjadi 83,33, berarti ada peningkatan sebesar 13,66 dan tingkat ketuntasan secara kelompok/klasikal pada siklus I mencapai 33,33\% dan pada siklus II meningkat menjadi $100 \%$. Hasil penelitian tindakan sekolah ini menunjukkan bahwa pembinaan kepala sekolah dapat meningkatkan kemampuan guru dalam menggunakan media pembelajaran pada proses pembelajarannya
\end{abstract}

Kata Kunci: Kemampuan guru, supervise akademik

\section{ABSTRACT}

The purpose of this school action research (PTS) is to find out the extent to which the supervision carried out by the principal followed by the provision of guidance/treatment to the target teachers can improve the teacher's ability to apply learning models in the classroom. In this school action research (PTS) it was conducted in 2 cycles, from the results of the actions taken it was proven to be able to improve the ability of teachers by achieving ideal standards. In the first cycle the teacher's ability to increase after classroom supervision was carried out after coaching on the use of new learning media reached about $33.33 \%$ in the second cycle it could increase to $100 \%$. The average score obtained after class supervision in the first cycle was 69.67 and increased in the second cycle to 83.33, meaning that there was an increase of 13.66 and the group/classical level of completeness in the first cycle reached $33.33 \%$ and in the second cycle increased to $100 \%$. The results of this school action research show that the coaching of the principal can improve the ability of teachers to use learning media in the learning process

Keywords: Teacher ability, academic supervision

\section{PENDAHULUAN}

Sistem pendidikan dewasa ini telah mengalami kemajuan yang sangat pesat. Berbagai cara sudah dikenal dalam peroses belajar mengajar (PBM) dengan harapan pengajar atau guru lebih mudah dalam mentransformasikan ilmu pengetahuan dan murid juga lebih mudah memahami apa yang disampaikan oleh guru dalam peroses pembelajaran (Pujilestari, 2020).

Sejak beberapa tahun terakhir teknologi informasi dan komunikasi telah banyak digunakan dalam peroses pembelajaran, dengan satu tujuan untuk mengangkat mutu dalam bidang ilmu pendidikan yang akan maju seiring berkembangnya teknologi (Anggraeni, dkk, 2018). Pendidikan merupakan program jangka panjang yang wajib dilaksanakan oleh semua orang, dan pendidikan juga sangat memerlukan usaha dan biaya yang cukup besar, hal ini diakui 


\section{Vol. 1 No. 3 Desember 2021 e-ISSN : 2797-3344 P-ISSN : 2797-3336}

oleh semua orang bahkan oleh suatu bangsa demi kelangsungan masa depan dari semua orang atau bangsa tersebut (Yanto, 2019). Begitu pula halnya dengan bangsa Indonesia yang menaruh harapan besar terhadap masalah pendidikan dalam perkembangan masa depan bangsa ini, karena dari pendidikanlah tunas muda harapan bangsa sebagai generasi penerus bisa dibentuk (Hasyim, 2014). Dan ini sesuai dengan tujuan pendidikan Nasional Indonesia, salah satunya yaitu Mencerdaskan kehidupan bangsa yang terdapat didalam Pembukaan Undang Undang Dasar Negara Republik Indinesia 1945.

Meski diakui bahwa pendidikan adalah investasi besar jangka panjang yang harus disiapkan, ditata, dan diberikan sarana maupun prasarana dalam arti modal material yang cukup besar, tetapi sampai saat ini Indonesia masih berkutat pada problematika atau permasalahan klasik dalam hal ini yaitu kualitas pendidikan dan hal ini perlu dicarikan solusinya agar tidak terperangkap dalam permasalahan tersebut (Putria, dkk, 2020).

Terkait dengan mutu pendidikan khususnya pendidika pada jenjang Sekolah Dasar (SD) dan Madrasah Ibtidaiyah (MI) sampai saat ini masih jauh dari apa yang kita harapkan, dan ini terbukti apa bila standar nilai kelulusan dinaikkan, pihak sekolah akan merasa terpukul dengan melihat banyaknya nilai siswa yang tidak sesuai dengan standar yang ditetapkan (Suryana, 2020). Semua ini bersumber dari salah satunya yaitu kurangnya penguasaan media pembelajaran Power Point yang dipakai guru dalam proses pembelajaran yang dapat meningkatkan motivasi siswa dalam belajar, hal ini tentunya juga biasa berpengaruh terhadap hasil belajar atau tarap serap terhadap siswa itu sendiri (Nugraha, 2018).

Program bermutu bertujuan untuk meningkatkan mutu pembelajaran sebagai dampak peningkatan Kemampuan, kualifikasi, dan Kemampuan guru. Salah satu komponen strategis Program bermutu untuk mencapai tujuan tersebut adalah penguatan peningkatan mutu dan profesional guru secara berkelanjutan yang terwadahi dalam komponen 2 program bermutu seperti kegiatan KKGS (Perdana, 2019). Program pada komponen 2 ini terkait dengan usaha memantapkan struktur pengembangan mutu guru pada tingkat lokal. Salah satu kegiatannya adalah pemberdayaan berbagai forum dan kelompok kerja guru, kepala sekolah, dan pengawas sekolah. Dalam upaya pemberdayaan kelompok kerja atau kelompok kerja tersebut, program bermutu mengembangkan Model Belajar bermutu serta Paket Pembelajaran bermutu yang akan menjadi salah satu aktivitas utama dari kelompok kerja dan forum tersebut (Djailani, dkk, 2014).

Berdasarkan Peraturan Menteri Pendidikan Nasional Nomor 13 Tahun 2007 tentang Standar Kepala Sekolah/Madrasah menegaskan bahwa seorang kepala sekolah/madrasah harus memiliki lima dimensi Kemampuan minimal yaitu: Kemampuan kepribadian, manajerial, kewirausahaan, supervisi, dan sosial. Strategi sosialisasi dan strategi bimbingan supervisi akademik yang telah dilaksanakan selama ini ternyata masih belum memadai untuk menjangkau seluruh kepala sekolah/Madrasah dalam waktu yang relatif singkat (Hidayat, dkk, 2019).

Kemampuan merupakan suatu kemampuan yang mutlak dimiliki guru agar tugasnya sebagai pendidik dapat terlaksana dengan baik. Kemampuan merupakan suatu hal yang tidak dapat dipisahkan dari kegiatan pendidikan dan pembelajaran di jalur sekolah. Kemampuan sebagai konsep dapat diartikan secara etimologis dan terminologis. Dalam pengertian etimologis Kemampuan dapat dikemukakan bahwa "Kemampuan tersebut berasal dari bahasa Inggris, yakni competency yang berarti kecakapan dan kemampuan. Oleh karena itu dapat pula dikatakan bahwa Kemampuan adalah kewenangan (kekuasaan) untuk menentukan (memutuskan) sesuatu. Selain itu juga dinyatakan oleh seorang ahli bahwa "Kemampuan adalah suatu tugas yang memadai atau pemilikan pengetahuan, keterampilan dan kemampuan yang dituntut oleh jabatan seseorang (Pianda, 2018).

Apabila pengertian siatas dihubungkan dengan proses pendidikan, maka guru sebagai pemegang jabatan pendidik dituntut untuk memiliki kemampuan dalam menjalankan tugasnya. Untuk itu, seorang guru perlu menguasai bahan pelajaran dan menguasai cara-cara mengajar serta memiliki kepribadian yang kokoh sebagai dasar Kemampuan. Jika guru tidak memiliki 
kepribadian, tidak menguasai bahan pelajaran serta tidak pula mengetahui cara-cara mengajar, maka guru akan mengalami kegagalan dalam menunaikan tugasnya. Oleh karena itu, Kemampuan mutelak dimiliki guru sebagai kemampuan, kecakapan atau keterampilan dalam mengelola kegiatan pendidikan. Dengan demikian, Kemampuan guru berarti pemilikan pengetahuan keguruan dan pemilikan keterampilan serta kemampuan sebagai guru dalam melaksanakan tugasnya sebagai pendidik (Musfah, 2012).

Profesi keguruan merupakan sebuah profesi yang strategis untuk membawa angin kemajuan pada semua aspek nilai-nilai kemanusiaan. Dengan demikian, guru tidak hanya sekedar berfungsi menyampaikan ilmu pengetahuan, tetapi lebih-lebih ia adalah pendidik yang bertugas mentrasfer dan mengembangkan nilai-nilai kemasyarakatan, sehingga dengan demikian tugas-tugas keguruan menuntut kemampuan yang majemuk dalam proses pendidikan, sehingga kemajuan ilmu pengetahuan, kecanggihan teknologi dan dinamika seni yang telah dicapai sekarang ini belum mampu menggantikan kehadiran seorang guru dalam proses belajar mengajar (Andina, 2018).

Peningkatan mutu pendidikan disekolah dapat dicapai melalui peningkatan kualitas sumber daya manusia (guru dan tenaga kependidikan lainya), walaupun diakui bahwa komponen-komponen lain turut memberikan kontribusi dalam peningkatan mutu pembelajaran. Mengingat peran pentingnya kehadiran seorang guru pada proses pendidikan itu, maka kemampuan-kemampuan yang seharusnya dimiliki sebagai pondasi profesinya adalah tonggak awal bagi keberhasilannya dalam menjalankan tugasnya (Sudrajat, 2020). Peningkatan sumber daya manusia telah banyak dilakukan oleh pemerintah, terutama peningkatan Kemampuan guru melalui pendidikan dan pelatihan, FGD, workshop, seminar, loka karya dan Supervisi Akademik. Kenyataan selama ini kondisi pendidikan kita masih saja belum mampu memberikan kontibusi maksimal dalam meningkatkan prestasi belajar siswa secara nasional masih belum maksimal sesuai dengan standar minimal yang ditetapkan oleh pemerintah.

\section{METODE PENELITIAN}

Jenis penelitian ini adalah penelitian tindakan Sekolah (PTS). Penelitian tindakan sekolah (PTS) merupakan suatu proses investigasi terkendali yang berdaur ulang dan bersifat reflektif mandiri yang dilakukan oleh kepala sekolah yang memiliki tujuan untuk melakukan perbaikan-perbaikan terhadap sistem, cara kerja, proses, isi, Kemampuan, atau situasi pembelajaran. Penelitian tindakan sekolah (PTS) dan dilaksanakan pada semester genap tahun pelajaran 2020/2021 ini.

Penelitian tindakan sekolah ini dilaksanakan di SDN 3 Beririjarak Kecamatan Wanasaba kabupaten Lombok Timur yang merupakan tempat tugas peneliti. Penelitian ini dilaksanakan dengan menggunakan dua siklus, dengan setiap siklusnya dilaksanakan proses pembimbingan berupa Penerapan model pembelajaran kemudian dilaksanakan observasi/penilaian berupa supervisi proses pembelajaran. Penelitian ini dilaksanakan selama kurang lebih tiga bulan, yaitu mulai Bulan Maret sampai dengan Mei 2021.

Subyek penelitian adalah guru-guru SDN 3 Beririjarak Kecamatan Wanasaba kabupaten Lombok Timur tahun pelajaran 2020/2021 yang berjumlah 3 orang guru Kelas Tinggi. Pada penelitian tindakan sekolah ini, memiliki cirri utama yaitu terdapat siklus-siklus yang tiap siklusnya memiliki tahapan-tahapan yaitu: a) perencanaan tindakan (planning), b) tindakan (acting), c) pengamatan (observasing), d) refleksi (reflecting). Sumber data penelitian ini berasal dari peneliti, observer, dan guru sasaran penelitian pada semester genap di SDN 3 Beririjarak Kecamatan Wanasaba.

\section{HASIL DAN PEMBAHASAN}

\section{Siklus I}

Tahap Perencanaan, Pada tahap ini peneliti mempersiapkan perangkat pembinaan yang terdiri dari rencana pembinaan 1, Instrumen 1, Evaluasi 1 dan alat-alat pembinaan yang mendukung. Selain itu juga dipersiapkan lembar observasi pengolaan pembelajaran. 
Vol. 1 No. 3 Desember 2021 e-ISSN : 2797-3344 P-ISSN : 2797-3336

Tahap Kegiatan dan Pelaksanaan, Pelaksanaan tindakan dalam penelitia siklus I. Pembinaan di laksanakan pada tanggal 5 dan 8 april 20021dan supervisi akademik pada siklus I dilaksanakan tanggal 12 s.d 17 April 2021 di SDN 3 Beririjarak Kecamatan Wanasaba. dengan jumlah guru 3 Orang. Dalam hal ini peneliti bertindak sebagai Kepala Sekolah. Adapun proses pembinaan mengacu pada rencana pelajaran yang telah dipersiapkan.

Pengamatan (observasi) dilaksanakan bersamaan dengan pelaksaaan belajar mengajar. Pada akhir proses pembinaan, guru dan kepala sekolah menyepakati waktu pelaksanaan supervisi di kelas dengan tujuan untuk mengetahui tingkat kemampuan guru dalam proses belajar mengajar yang telah dilakukan. Adapun data hasil penelitian pada siklus I. adalah seperti pada tabel berikut :

Tabel 1 Tabel hasil Supervisi Akademik Pada Siklus I

\begin{tabular}{llccc} 
& & \multicolumn{3}{c}{ Keterangan } \\
No & \multicolumn{1}{c}{ Nama Guru } & Skor & Tuntas & $\begin{array}{c}\text { Tidak } \\
\text { Tuntas }\end{array}$ \\
& & & & $\sqrt{ }$ \\
1 & Hj.Hasanah, S.Pd.SD & 65 & $\sqrt{ }$ & \\
2 & Lukmanul Hakim, S.Pd & 75 & $\sqrt{ }$ & - \\
3 & LL.Rasidin,S.Pd & 69 & & - \\
Jumlah Nilai & 209 & - & - \\
Nilai rata-rata & 69,67 & - & \\
\% Jumlah Guru Yang Mencapai nilai & $33,33 \%(=1$ guru $)$ \\
Supervisi Akademik minimal 75 & \multicolumn{3}{l}{} \\
\hline
\end{tabular}

Dari tabel di atas dapat dijelaskan bahwa dengan menerapkan supervisi akademik kepala sekolah diperoleh nilai rata-rata Kemampuan guru adalah 69,67 dan ada 1 orang guru dari 3 orang, sudah meningkat mutunya dalam proses belajar mengajar. Hasil tersebut menunjukkan bahwa pada siklus pertama secara kelompok guru (sekolah) belum meningkat mutunya, karena guru yang memperoleh nilai $\geq 75$ hanya sebesar $33,33 \%$ artinya lebih kecil dari persentase ketuntasan yang dikehendaki yaitu sebesar $\geq 85 \%$. Hal ini disebabkan karena guru masih merasa baru dan belum mengerti apa yang dimaksudkan dan dijelaskan oleh Kepala Sekolah dalam pembinaan kaitan dengan penerapan model pembelajaran oleh guru-guru tersebut masih agak mengalami kesulitan dalam penyampaian materi pembelajaran.

Refleksi, Dalam pelaksanaan kegiatan belajar mengajar diperoleh informasi dari hasil pengamatan sebagai berikut: 1) Kepala Sekolah kurang maksimal dalam memotivasi guru dan dalam menyampaikan tujuan pembinaan. 2) Guru kurang mampu dalam pengelolaan waktu. 3) Guru masih kurang begitu antusias dan termotivasi selama pembelajaran berlangsung.

Revisi Rancangan, Pelaksanaan kegiatan pembinaan pada siklus I ini masih terdapat kekurangan, sehingga perlu adanya revisi untuk dilakukan pada siklus berikutnya. 1) Kepala Sekolah perlu lebih terampil dalam memotivasi guru dan lebih jelas dalam menyampaikan tujuan pembinaan. Di mana guru diajak untuk terlibat langsung dalam setiap kegiatan yang dilakukan. 2) Guru perlu mendistribusikan waktu secara baik dengan menambahkan informasiinformasi yang dirasa perlu dan memberi catatan. 3) Kepala Sekolah harus lebih terampil dan bersemangat dalam memotivasi guru sehingga guru bisa lebih antusias.

\section{Siklus II}

Tahap perencanaan, Pada tahap ini peneliti mempersiapkan perangkat pembinaan yang terdiri dari rencana pembinaan 2, lembar observasi dan alat-alat pembinaan yang mendukung.

Tahap kegiatan dan pelaksanaan, Pelaksanaan kegiatan pembinaan pada siklus 2 pada tanggal 19dan 22 april 2021 dan supervisi akademik siklus II dilaksanakan pada tanggal 26 April s.d 1 Mei 2021di SDN 3 Beririjarak Kecamatan Wanasaba Kabupaten Lombok Timur tahun pelajaran 2020/2021 Dalam hal ini peneliti bertindak sebagai Kepala Sekolah. Adapun proses pembinaan mengacu pada rencana pembinaan dengan memperhatikan revisi pada siklus 
Vol. 1 No. 3 Desember 2021 e-ISSN : 2797-3344 P-ISSN : 2797-3336

I, sehingga kesalahan atau kekurangan pada siklus I tidak terulang lagi pada siklus II. Pengamatan (observasi) dilaksanakan bersamaan dengan pelaksanaan belajar mengajar.

Pada akhir proses pembinaan, guru dan kepala sekolah menyepakati waktu supervisi di kelas dengan tujuan untuk mengetahui peningkatan kemampuan guru dalam proses pembinaan yang telah dilakukan. Instrumen yang digunakan adalah tes formatif II. Adapun data hasil penelitian pada siklus II adalah sebagai berikut :

Tabel 2 Distribusi Skor Hasil Supervisi Akademik Kemampuan Guru menerapkan model pembelajaran Pada Siklus II

\begin{tabular}{llccc} 
& & \multicolumn{3}{c}{ Keterangan } \\
No & Nama Guru & Skor & Tuntas & $\begin{array}{c}\text { Tidak } \\
\text { Tuntas }\end{array}$ \\
& & & $\sqrt{ }$ & \\
1 & Hj.Hasanah,, S.Pd.SD & 90 & $\sqrt{ }$ & \\
2 & Lukmanul Hakim, S.Pd & 81 & $\sqrt{ }$ & - \\
Jumlah Nilai & LL.Rasidin,S.Pd & 250 & - & - \\
Nilai rata-rata & 83,33 & - & - \\
\% Jumlah Guru Yang Mencapai nilai & $100 \%(=3$ guru $)$ & \\
Supervisi Akademik minimal 75 & - & & \\
\hline
\end{tabular}

Dari tabel di atas diperoleh nilai rata-rata peningkatan kemampuan guru adalah 83,33 dan ketuntasan pembinaan mencapai $100 \%$ atau semua guru yang dijadikan sasaran penelitian sudah meningkat mutunya dalam proses belajar mengajar. Hasil ini menunjukkan bahwa pada siklus II ini ketuntasan belajar 100\%Dari data-data yang telah diperoleh dapat duraikan sebagai berikut : 1) Selama proses pembinaan Kepala Sekolah telah melaksanakan semua pembinaan dengan baik. Meskipun ada beberapa aspek yang belum sempurna, tetapi persentase pelaksanaannya untuk masing-masing aspek cukup besar. 2) Berdasarkan data hasil pengamatan diketahui bahwa guru aktif selama proses belajar berlangsung. 3) Kekurangan pada siklus-siklus sebelumnya sudah mengalami perbaikan dan peningkatan sehingga menjadi lebih baik. 4) Hasil pembinaan guru oleh kepala sekolah melalui supervisi akademik pada siklus II mencapai ketuntasan $100 \%$.

Pada siklus II guru telah menerapkan model pembelajaran melalui pembinaan kepala sekolah dengan baik dan dilihat dari aktivitas guru serta hasil pembinaan guru pelaksanaan proses pembinaan sudah berjalan dengan baik. Maka tidak diperlukan revisi terlalu banyak, tetapi yang perlu diperhatikan untuk tindakan selanjutnya adalah memaksimalkan dan mempertahankan apa yang telah ada dengan tujuan agar pada pelaksanaan proses belajar mengajar selanjutnya pembinaan yang dilakukan Kepala Sekolah dapat meningkatkan kemampuan guru dalam proses belajar mengajar dalam menerapkan model pembelajaran sehingga tujuan pembelajaran dapat tercapai.

Setelah dilakukan tindakan pada siklus 1, dan siklus 2 menunjukkan hasil sebagai berikut.

Tabel 3 Analisis Hasil Observasi Kemampuan Guru Pada Siklus I dan Siklus II Melalui Supervisi Akademik

\begin{tabular}{llcc}
\hline No & Nama & $\begin{array}{c}\text { Skor Perolehan } \\
\text { Pada Siklus I }\end{array}$ & $\begin{array}{c}\text { Skor } \\
\text { Pada Siklus II }\end{array}$ \\
1 & Hj.Hasanah, S.Pd.SD & 65 & 79 \\
2 & Lukmanul Hakim, S.Pd & 75 & 90 \\
3 & LL.Rasidin,S.Pd & 69 & 81 \\
Jumlah Nilai & 209 & 250 \\
Nilai rata-rata & 69,67 & 83,33 \\
\% Jumlah Guru Yang Mencapai nilai & $33,33 \%$ & $100 \%$ \\
supervisi akademik minimal 75 & $(1$ guru $)$ & $(3$ guru $)$ \\
\hline
\end{tabular}




\section{Vol. 1 No. 3 Desember 2021 e-ISSN : 2797-3344 P-ISSN : 2797-3336}

Dari hasil analisis tersebut dapat disimpulkan bahwa : A) Terjadi peningkatan rata-rata hasil kemampuan guru dari siklus I ke siklus II yaitu dari 69,67 menjadi 83,33 ada kenaikan sebesar 13,66. B) Terjadi peningkatan jumlah guru yang mencapai hasil Kemampuan $\geq 75$ dari siklus I ke siklus II yaitu dari 1 orang menjadi 3 orang artinya semua sasaran telah mencapai ketuntasan.

\section{Pembahasan}

Berdasarkan hasil penelitian ini menunjukkan bahwa penerapan model pembelajaran melalui binaan Kepala Sekolah memiliki dampak positif dalam meningkatkan kemampuan guru. Hal ini dapat dilihat dari semakin mantapnya pemahaman guru dari pembinaan yang diberikan oleh kepala sekolah (rata-rata hasil Kemampuan guru meningkat dari siklus I, dan II) yaitu masing-masing 69,67 dan ; 83,33. Pada siklus II ketuntasan pembinaan guru secara kelompok telah tercapai.

Berdasarkan analisis data, diperoleh aktivitas guru dalam pembinaan yang dilakukan Kepala Sekolah dalam menerapkan model pembelajaran dalam setiap siklus mengalami peningkatan. Hal ini berdampak positif terhadap peningkatan kemampuan guru yaitu dapat ditunjukkan dengan meningkatnya nilai rata-rata yang dicapai guru pada setiap siklus yang terus mengalami peningkatan.

Berdasarkan analisis data, diperoleh aktivitas guru dan Kepala Sekolah dalam proses pembinaan melalui penerapan model pembelajaran yang paling dominan adalah bekerja dengan menggunakan alat/media, mendengarkan / memperhatikan penjelasan Kepala Sekolah, dan diskusi antar guru antara guru dan Kepala Sekolah. Jadi dapat dikatakan bahwa aktivitas guru dapat dikategorikan aktif. Sedangkan untuk aktivitas Kepala Sekolah selama pembinaan telah melaksanakan langkah-langkah pembinaan pelatihan berkelanjutan dengan baik. Hal ini terlihat dari aktivitas Kepala Sekolah yang muncul di antaranya aktivitas membimbing dan mengamati guru dalam mengerjakan kegiatan pembelajaran, menjelaskan, memberi umpan balik/evaluasi/tanya jawab di mana prosentase untuk aktivitas di atas cukup besar.

Berdasarkan hasil penelitian di atas, maka hasil pembinaan Kepala Sekolah hasilnya sangat baik. Hal itu tampak pada pertemuan pertama dari 3 Orang guru yang hadir pada saat penelitian ini dilakukan ketuntasan pencapaian Kemampuan ideal dari siklus I dan siklus II masing-masing yaitu 33,33\% meningkat menjadi $100 \%$

Dari analisis data di atas bahwa pembinaan dalam meningkatkan kemampuan guru dalam menerapkan model pembelajaran melalui pembinaan Kepala Sekolah, yang berarti proses kegiatan belajar mengajar lebih berhasil dan dapat meningkatkan mutunya khususnya di SDN 3 Beririjarak kecamatan Wanasaba kabupaten Lombok Timur, oleh karena itu diharapkan kepada para guru SDN 3 Beririjarak dapat meningkatkan mutunya dalam melaksanakan pembelajaran di kelas.

Berdasarkan manajemen berbasis sekolah (MBS) dikatakan tuntas apabila guru telah mencapai nilai KKM sebesar 75 mencapai $\geq 83,33 \%$. Sedangkan pada penilitian ini, pencapaian nilai $\geq 75$ pada ( siklus II ) mencapai melebihi target yang ditetapkan dalam MBS yaitu mencapai $100 \%$.

\section{KESIMPULAN}

Dari hasil kegiatan pembinaan yang telah dilakukan selama dua siklus, dan berdasarkan seluruh pembahasan serta analisis yang telah dilakukan dapat disimpulkan sebagai berikut : Penerapan Supervisi Akademik dapat meningkatkan Kemampuan guru dalam memanfaatkan media pembelajaran Pada masa pandemi copid-19 di SDN 3 Beririjarak kecamatan Wanasaba tahun pelajaran 2020/2021.

\section{DAFTAR PUSTAKA}

Andina, E. (2018). Efektivitas pengukuran kompetensi guru. Aspirasi: Jurnal MasalahMasalah Sosial, 9(2), 204-220. 


\section{Vol. 1 No. 3 Desember 2021 e-ISSN : 2797-3344 P-ISSN : 2797-3336}

Anggraeni, P., \& Akbar, A. (2018). Kesesuaian rencana pelaksanaan pembelajaran dan proses pembelajaran. Jurnal Pesona Dasar, 6(2).

Djailani, A. R., \& Ibrahim, S. (2014). Penerapan Manajemen Berbasis Sekolah Dalam Meningkatkan Mutu Pendidikan Di SD Negeri 62 Kota Banda Aceh. Jurnal Administrasi Pendidikan: Program Pascasarjana Unsyiah, 2(2).

Hasyim, M. H. M. (2014). Penerapan fungsi guru dalam proses pembelajaran. AULADUNA: Jurnal Pendidikan Dasar Islam, 1(2), 265-276.

Hidayat, R., \& Ulya, H. (2019). Kompetensi kepala sekolah abad 21: Sebuah tinjauan teoretis. Jurnal Kepemimpinan dan Pengurusan Sekolah, 4(1), 61-68.

Musfah, J. (2012). Peningkatan kompetensi guru: Melalui pelatihan dan sumber belajar teori dan praktik. Kencana.

Nugraha, M. (2018). Manajemen Kelas Dalam Meningkatkan Proses Pembelajaran. Tarbawi: Jurnal Keilmuan Manajemen Pendidikan, 4(01), 27-44.

Perdana, N. S. (2019). Implementasi PPDB zonasi dalam upaya pemerataan akses dan mutu pendidikan. Jurnal Pendidikan Glasser, 3(1), 78-92.

Pianda, D. (2018). Kinerja guru: kompetensi guru, motivasi kerja dan kepemimpinan kepala sekolah. CV Jejak (Jejak Publisher).

Pujilestari, Y. (2020). Dampak positif pembelajaran online dalam sistem pendidikan Indonesia pasca pandemi covid-19. Adalah, 4(1).

Putria, H., Maula, L. H., \& Uswatun, D. A. (2020). Analisis proses pembelajaran dalam jaringan (daring) masa pandemi covid-19 pada guru sekolah dasar. Jurnal Basicedu, 4(4), 861870.

Sudrajat, J. (2020). Kompetensi guru di masa pandemi COVID-19. Jurnal Riset Ekonomi Dan Bisnis, 13(1), 100-110.

Suryana, S. (2020). Permasalahan mutu pendidikan dalam perspektif pembangunan pendidikan. Edukasi, 14(1).

Yanto, D. T. P. (2019). Praktikalitas Media Pembelajaran Interaktif pada Proses Pembelajaran Rangkaian Listrik. INVOTEK: Jurnal Inovasi Vokasional dan Teknologi, 19(1), 7582. 